RASĀYAN J. Chem.

Vol. 13 | No. 2 |796 - 802| April - June | 2020 ISSN: 0974-1496 | e-ISSN: 0976-0083 | CODEN: RJCABP http://www.rasayanjournal.com http://www.rasayanjournal.co.in

\title{
CHEMICAL CONSTITUENTS AND ANTIOXIDANT ACTIVITY OF Salix tetrasperma ROXB
}

\author{
F. Utari, A. Itam, Syafrizayanti, and M. Efdi* \\ Department of Chemistry, Andalas University, Padang-25163, Indonesia \\ *E-mail: maiefdi@sci.unand.ac.id
}

\begin{abstract}
Six (1-6) and two (7-8) compounds were obtained from ethyl acetate extract of $S$. tetrasperma Roxb bark and leaves, respectively. Structures of isolated compounds were determined by spectroscopic data, including ${ }^{1} \mathrm{H}$ NMR, ${ }^{13} \mathrm{C}$ NMR, and two dimensional NMR as $\beta$-sitosterol glucoside (1), 3,4-dihydroxybenzoic acid (2), 2(hydroxymethyl)phenol (3), 1,3-dihydroxyphenol (4), 3-(hydroxymethyl)phenol (5), 4-methylbenzaldehyde (6), 1,2dihydroxybenzene (7) and 3',4',5,7-tetrahydroxyflavone (8). Interestingly, compounds 2, 4, 5, 6, and 8 were reported for the first time isolated from this plant. The antioxidant activities of all crude extracts were evaluated by the diphenylpicrilhydrazyl (DPPH) method. Among all extracts, methanol extract of the bark has the highest antioxidant activity with an $\mathrm{IC}_{50}$ value of $6.85 \mu \mathrm{g} / \mathrm{mL}$. The activity of ethyl acetate extract of the root (IC $\mathrm{IC}_{50} 19.53$ $\mu \mathrm{g} / \mathrm{mL}$ ) was stronger than the bark ( $\left.\mathrm{IC}_{50} 22.69 \mu \mathrm{g} / \mathrm{mL}\right)$.
\end{abstract}

Keywords: Salix tetrasperma Roxb, NMR, Antioxidant Activity, DPPH Method.

(C) RASĀYAN. All rights reserved

\section{INTRODUCTION}

Salix tetrasperma Roxb belongs to the Salicaceae family. This plant is commonly called "dalu-dalu" in West Sumatera, Indonesia and has been used as a traditional medicine to treat coughs and skin diseases as well as to reduce fever. The pharmacological activities of this plant showed that the bark extract of this plant possessed hypoglycemic activity ${ }^{1}$, while the leaf extract showed antimicrobial ${ }^{2}$, antipyretic ${ }^{3}$, analgesic, and anti-inflammatory activities. ${ }^{4}$ The previous phytochemical work on this genus revealed that most species contain numerous phenolic compounds. According to our previous study, the polyphenolic compounds showed good biological activities ${ }^{5-6}$ Salicin glycosides from $S$. glandulosa showed antineuroinflammatory activity. ${ }^{7}$ Recently the salicin derivatives from $S$. acmophylla were reported as cytotoxic and anti-inflammatory. ${ }^{8}$ Simple phenolic compounds from $S$. capensis bark had the antibacterial activity to $P$. aerugino. ${ }^{9}$ Only a few phytochemical studies have been reported on $S$. tetrasperma Roxb. ${ }^{410-11}$ The phytochemical composition of Salix from different regions may vary, due to the environment of the growing plant. However, the information on chemical constituents from $S$. tetrasperma Roxb growing in Indonesia is still limited. Due to a large number of phenolic compounds that were reported from this genus, the authors are also interested to evaluate the antioxidant activity from various parts of this plant. Hence, this study aims to isolate secondary metabolite compounds from ethyl acetate extract of $S$. tetrasperma Roxb bark and leaves and to investigate the antioxidant activity of $n$ hexane, ethyl acetate, and methanol extracts various parts of $S$. tetrasperma Roxb.

\section{EXPERIMENTAL}

Material and Methods

All solvents were purchased from the suppliers with further purification before usage. Silica gel for column chromatography was performed on silica gel 60 (Merck). TLC plates pre-coated with silica gel 70 $\mathrm{F}_{254}$ (60-200 mesh) were purchased from Wako Pure Chemical Industries, Japan. TLC spots were detected under the UV lamp (254 and $365 \mathrm{~nm}$ ). ${ }^{1} \mathrm{H},{ }^{13} \mathrm{C}$, HMQC, HMBC, and ${ }^{1} \mathrm{H}-{ }^{1} \mathrm{H}$ COSY NMR spectra were recorded with JEOL JNM-ECS 400, 500, and 600 spectrometers using TMS as an internal standard. Twodimensional ${ }^{1} \mathrm{H}^{-1} \mathrm{H}$ COSY, HMQC, and $\mathrm{HMBC}$ correlations were made by using standard pulse sequences.

Rasayan J. Chem., 13(2), 796-802(2020)

http://dx.doi.org/10.31788/RJC.2020.1325547

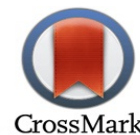


RASĀYAN J. Chem.

Vol. 13 | No. 2 |796 - 802| April - June | 2020

\section{Plant Material}

Leaves, root, and bark of $S$. tetrasperma Roxb were collected from the surrounding of Singkarak Lake, West Sumatera Province, Indonesia in May 2015. The plant was identified by a taxonomist at Herbarium of Andalas University (ANDA), Padang, Indonesia.

\section{Extraction and Isolation}

Each of the powdered samples ( $5 \mathrm{~kg}$ of leaves, $200 \mathrm{~g}$ of the root, and $11 \mathrm{~kg}$ of bark) was macerated in $n$ hexane for 3 days at room temperature and the process was repeated 4 times. All $n$-hexane filtrates of each part were concentrated by a rotary evaporator. The residue was immersed in ethyl acetate (EtOAc) and lastly followed in methanol $(\mathrm{MeOH})$ in the same aforementioned process.

The crude EtOAc extract of the bark $(100 \mathrm{~g})$ was fractionated on silica gel 60 , eluted with increasing polarity of solvents $(100 \% n$-hexane, dichloromethane (DCM), EtOAc until $100 \% \mathrm{MeOH})$ to afford nineteen fractions (A-S). Fraction R (12.22 g) was recrystallized with $\mathrm{MeOH}$ to obtain compound 1 (50 $\mathrm{mg}$ ) as a white powder that turned into purple after treatment with $10 \% \mathrm{H}_{2} \mathrm{SO}_{4}$ on the TLC plate. Fraction $\mathrm{K}(0.787 \mathrm{~g})$ was purified on CC, eluted with a mixture of $n$-hexane/DCM $(1: 0 \rightarrow 0: 1, \mathrm{v} / \mathrm{v}), \mathrm{DCM} / \mathrm{EtOAc}$ $(1: 0 \rightarrow 0: 1, \mathrm{v} / \mathrm{v})$ to yield nine fractions $(\mathrm{K} 1-\mathrm{K} 9)$. Compound $2(8 \mathrm{mg})$ was attained from fraction $\mathrm{K} 4$ as a yellow crystal. Fraction $\mathrm{G}(0.455 \mathrm{~g})$ was separated on CC $(\mathrm{DCM} / \mathrm{EtOAc}, 1: 0 \rightarrow 1: 1$, v/v) to give 16 fractions (G1-G16). Fraction G7 (50 mg) was purified on CC to give compound $3(6 \mathrm{mg})$ as an orange crystal and compound $4(4 \mathrm{mg})$ was acquired from fraction G14 as a white crystal. Fraction D (5.2 g) was separated into $\mathrm{SiO}_{2}$ to yield five sub-fractions (D1-D5). Fraction D1 (1.04 g) was separated on sephadex $(\mathrm{DCM} / \mathrm{MeOH}, 1: 1, \mathrm{v} / \mathrm{v})$ to give three fractions (D11-D13). Fraction D13 $(0.450 \mathrm{~g})$ was purified using CC $(n$-Hex/EtOAc, $4: 1, \mathrm{v} / \mathrm{v})$ to give compound $\mathbf{5}(10 \mathrm{mg})$ as an orange crystal. Fraction E $(8.30 \mathrm{~g})$ was separated on CC to give eight fractions (E1-E8). Fraction E2 (4.76 g) was separated on CC (DCM/EtOAc, $1: 0 \rightarrow 0: 1, \mathrm{v} / \mathrm{v})$ to obtain nine fractions (E21-E29). Fraction E24 $(30 \mathrm{mg})$ was purified on sephadex by using $\mathrm{MeOH}$ to get compound $6(3 \mathrm{mg})$ and was attained as a brownish crystal. The dried EtOAc extract of the leaves $(60 \mathrm{~g})$ was separated on silica gel with $n$-hexane $/ \mathrm{CHCl}_{3}(1: 1, \mathrm{v} / \mathrm{v}), \mathrm{CHCl}_{3} / \mathrm{MeOH}$ $(10: 0 \rightarrow 0: 10, \mathrm{v} / \mathrm{v})$ to give seven fractions (L1-L7). Fraction L5 (3 g) was chromatographed on silica gel to yield four sub-fractions (L51-L54). The fraction of L52 (1 g) was purified using silica gel $\left(\mathrm{CHCl}_{3} / \mathrm{EtOAc}\right)$ to obtain compound $7(70 \mathrm{mg})$ as a colorless crystal. Fraction L6 $(5 \mathrm{~g})$ was separated on silica gel $\left(\mathrm{CHCl}_{3} / \mathrm{EtOAc}\right.$, EtOAc/MeOH, 10:0 $\rightarrow 0: 10$, v/v) to yield ten sub-fractions (L61-L610). Compound 7 was also obtained from fraction L62. The recrystallization of fraction L66 obtained compound 8 (40 mg).

\section{Spectral Data \\ $\beta$-Sitosterol Glucoside (1)}

H NMR (500 MHz, DMSO- $\left.d_{6}\right) \delta$ ppm: 0.65 (3H, s, H-18), $0.81(3 \mathrm{H}, \mathrm{d}, J=8 \mathrm{~Hz}, \mathrm{H}-27), 0.80$ (3H, d, $J=$ $8 \mathrm{~Hz}, \mathrm{H}-26), 0.83$ (3H, s, H-19), 0.89 (3H, d, $J=6.5 \mathrm{~Hz}, \mathrm{H}-21), 0.95$ (3H, d, $J=8 \mathrm{~Hz}, \mathrm{H}-29), 3.12(1 \mathrm{H}$, m, H-3), 3.05 (1H, d, $J=5.2 \mathrm{~Hz}, \mathrm{H}-2$ ') 3.46 (1H, m, H-4'), 3.64 (1H, dd, $J=5.2 \mathrm{~Hz}, \mathrm{H}-5$ '), 4.21 (1H, d, $\left.J=7.8 \mathrm{~Hz}, \mathrm{H}-3^{\prime}\right), 4.43\left(1 \mathrm{H}, \mathrm{t}, J=5.2 \mathrm{~Hz}, \mathrm{H}-1^{\prime}\right), 4.87$ (1H, t, $J=5.2 \mathrm{~Hz}, \mathrm{H}-6$ 'b), 4.90 (1H, dd, $J=4.5 \mathrm{~Hz}$, H-6'a); and $5.38(1 \mathrm{H}$, brs, $J=4.5 \mathrm{~Hz}, \mathrm{H}-6)$. C NMR (125 MHz, DMSO- $\left.d_{6}\right) \delta$ ppm: $36.83(\mathrm{C}-1), 29.27(\mathrm{C}-$ 2), 76.87 (C-3), 39.28 (C-4), 140.44 (C-5), 121.22 (C-6), 31.42 (C-7), 31.37 (C-8), 49.60 (C-9), 36.21 (C10), 20.60 (C-11), 38.30 (C-12), 41.86 (C-13), 56.17 (C-14), 23.87 (C-15), 27.80 (C-16), 55.42 (C-17), 11.68 (C-18), 19.11 (C-19), 35.48 (C-20), 18.62 (C-21), 33.34 (C-22), 25.43 (C-23), 45.14 (C-24), 28.70 (C-25), 19.72 (C-26), 18.94 (C-27), 22.61 (C-28), 11.79 (C-29), 100.77 (C-1'), 73.47 (C-2'), 76.91 (C3'), 70.11 (C-4'), 76.75 (C-5'), 61.10 (C-6').

\section{3, 4-Dihydroxybenzoic Acid (2)}

H NMR (500 MHz, DMSO- $d_{6}$ ) $\delta$ ppm: 12.28 (brs), 9.62 (brs), 9.30 (brs), 7.33 (d, 1H, $J=2.1 \mathrm{~Hz}, \mathrm{H}-2$ ), 7.28 (dd, $1 \mathrm{H}, J=8.2 ; 2.1 \mathrm{~Hz}, \mathrm{H}-6), 6.77$ (d, $1 \mathrm{H}, J=8.2 \mathrm{~Hz}, \mathrm{H}-5)$. C NMR (125 MHz, DMSO- $\left.d_{6}\right) \delta$ ppm: 168.24 (C-7), 150.60 (C-4), 145.41 (C-3), 122.73 (C-6), 122.20 (C-1), 117.08 (C-2), 115.811 (C-5).

\section{2-(Hydroxymethyl) Phenol (3)}

H NMR (400 MHz, Acetone- $\left.d_{6}\right) \delta$ ppm: $7.21(\mathrm{~d}, 1 \mathrm{H}, J=7.32 \mathrm{~Hz}, \mathrm{H}-3), 7.07$ (t, $\left.1 \mathrm{H}, J=8.24 \mathrm{~Hz}, \mathrm{H}-5\right)$, 6.78 (t, $1 \mathrm{H}, J=7.32 ; 8.24 \mathrm{~Hz}, \mathrm{H}-4), 6.77$ (d, 1H, $J=8.24 \mathrm{~Hz}, \mathrm{H}-6), 4.71$ (s, 2H, H-7). C NMR (100 MHz, 
RASĀYAN J. Chem.

Vol. 13 | No. 2 |796 - 802| April - June | 2020

Acetone- $\left.d_{6}\right) \delta$ ppm: 155.36 (C-1), 127.99 (C-3), 127.53 (C-5), 127.45 (C-2), 119.32 (C-4), 115.17 (C-6), $61.02(\mathrm{C}-7)$.

\section{1, 3-Dihydroxyphenol (4)}

H NMR (400 MHz, Acetone- $\left.d_{6}\right) \delta$ ppm: $7.88(\mathrm{dd}, 1 \mathrm{H}, J=2.28 ; 1.84 \mathrm{~Hz}, \mathrm{H}-2), 7.51$ (td, $1 \mathrm{H}, J=7.76 ; 1.84$ $\mathrm{Hz}, \mathrm{H}-5), 6.91$ (dd, $2 \mathrm{H}, J=8 ; 0.92 \mathrm{~Hz}, \mathrm{H}-4$ and H-6). C NMR (100 MHz, Acetone- $\left.d_{6}\right) \delta$ ppm: 135.9 (C-1 and C-3), 130.45 (C-5), 119.00 (C-4 and C-6), 117.00 (C-2).

\section{3-(Hydroxymethyl) Phenol (5)}

H NMR (400 MHz, CDCl $) \delta$ ppm: 7.21 (td, $1 \mathrm{H}, J=8 ; 0.92 \mathrm{~Hz}, \mathrm{H}-5), 7.03(\mathrm{dd}, 1 \mathrm{H}, J=8 ; 1.36 \mathrm{~Hz}, \mathrm{H}-6)$, 6.87 (dd, $1 \mathrm{H}, J=1.36 ; 0.92 \mathrm{~Hz}, \mathrm{H}-4), 6.84$ (dd, $1 \mathrm{H}, J=8 ; 1.36 \mathrm{~Hz}, \mathrm{H}-2), 4.85$ (s, 2H, H-7). C NMR (100 $\mathrm{MHz}, \mathrm{CDCl}_{3}$ ) $\delta$ ppm: 156.14 (C-1), 129.61 (C-3), 127.92 (C-5), 124.73 (C-4), 120.18 (C-6), 116.62 (C2), $64.74(\mathrm{C}-7)$.

\section{4-Methylbenzaldehyde (6)}

H NMR (400 MHz, Acetone- $d_{6}$ ) $\delta$ ppm: 9.13 (brs), 7.87 (dd, 2H, $J=8$; $4 \mathrm{~Hz}, \mathrm{H}-2$ and H-6), 6.90 (dd, 2H, $J=8 ; 4 \mathrm{~Hz}, \mathrm{H}-3$ and H-5), 2.46 (s, 3H, Me). C NMR (100 MHz, Acetone- $\left.d_{6}\right) \delta$ ppm: $195.73(\mathrm{C}-7), 161.86$ (C-4), 130.79 (C-2 and C-6), 129.66 (C-1), 115.19 (C-3 and C-5), 28.90 (Me).

\section{1, 2-Dihydroxybenzene (7)}

H NMR (400 MHz, Acetone- $\left.d_{6}\right) \delta$ ppm: 6.67 (m, 2H, H-3 and H-6), 6.82 (m, 2H, H-4 and H-5). C NMR (125 MHz, Acetone- $d_{6}$ ) $\delta$ ppm: 145.14 (C-1 and C-2), 119.97 (C-3 and C-6), 115.38 (C-4 and C-5).

\section{3', 4', 5, 7-Tetrahydroxyflavone (8)}

H NMR (600 MHz, Methanol- $\left.d_{3}\right) \delta$ ppm: 7.38 (d, $1 \mathrm{H}, J=2.76 \mathrm{~Hz}, \mathrm{H}-2$ ') 7.37 (d, $1 \mathrm{H}, J=8.94 \mathrm{~Hz}, \mathrm{H}-6$ '), 6.90 (d, 1H, $J=8.94 \mathrm{~Hz}, \mathrm{H}-5$ '), 6.53 (s, 1H, H-3), 6.43 (d, 1H, $J=2.04 \mathrm{~Hz}, \mathrm{H}-8), 6.20$ (d, 1H, $J=2.04$ Hz, H-6). C NMR (150 MHz, Methanol- $d_{3}$ ) $\delta$ ppm: 182.52 (C-4), 165.00 (C-7), 164.65 (C-2), 161.87 (C5), 158.06 (C-9), 149.64 (C-4'), 145.70 (C-3'), 122.33 (C-1'), 118.94 (C-6'), 115.42 (C-5'), 112.80 (C2'), 103.96 (C-10), 102.51 (C-3), 98.75 (C-6), 93.63 (C-8).

\section{Antioxidant Activity}

The antioxidant activities of various $S$. tetrasperma Roxb extracts were determined by using DPPH radical scavenged method ${ }^{12}$ with slight modification. $3 \mathrm{~mL}$ of each solution [in various concentrations] of tested samples ( $n$-hexane, EtOAc, and $\mathrm{MeOH}$ extracts of the leaves, roots, and bark) was poured into 1 $\mathrm{mL}$ of DPPH solution $[0.1 \mathrm{mmol} / \mathrm{L}]$. The mixture was incubated for 30 minutes at room temperature in the dark place and then recorded by UV-spectrophotometer at $517 \mathrm{~nm}$. As a comparison, the ascorbic acid and methanol were used as a standard and a blank, respectively. The antioxidant activity was calculated based on the percentage of DPPH radical scavenged (\% Inhibition) using the following equation:

$$
\% \text { Inhibition }=\frac{(\text { A control }- \text { A sample })}{A \text { control }} \times 100
$$

Where $A_{\text {control }}$ is the absorbance of control containing all reagents that exclude the sample, and $A_{\text {sample }}$ is the absorbance of the sample. The measurements were taken in triplicate. The antioxidant results were expressed as the $\mathrm{IC}_{50}$ value \pm standard deviation (SD).

\section{Characterization of Isolated Compounds}

\section{RESULTS AND DISCUSSION}

After separation by chromatography technique, six (1-6) and two (7-8) compounds were isolated from EtOAc extract of $S$. tetrasperma Roxb bark and leaves, respectively. The structures of isolated compounds were displayed in Fig.-1.

Compound 1 was acquired as a white powder $(50 \mathrm{mg})$. The $\mathrm{H}$ NMR spectrum of 1 showed the presence of a broad singlet signal at $\delta_{\mathrm{H}} 5.38 \mathrm{ppm}$ characterized as an olefinic proton $(\mathrm{H}-6)$. While one proton as a 
RASĀYAN J. Chem.

Vol. 13 | No. 2 |796 - 802| April - June | 2020

multiplet at $\delta_{\mathrm{H}} 3.12 \mathrm{ppm}$ was assigned as an oxymethine proton (H-3). A steroidal nucleus was assigned by the presence of two protons at $\delta_{\mathrm{H}} 3.12(\mathrm{H}-3)$ and $5.38(\mathrm{H}-6)$.<smiles>CCC(CCC(C)C1CCC2C3CC=C4CC(OC5OCC(O)C(O)C(O)C5O)CCC4(C)C3CCC12C)C(C)C</smiles><smiles>O=C(O)c1ccc(O)c(O)c1</smiles><smiles>OCc1ccccc1O</smiles><smiles>Oc1cccc(O)c1</smiles>

4<smiles>OCc1cccc(O)c1</smiles>

5<smiles>Cc1ccc(C=O)cc1</smiles>

6<smiles>Oc1ccccc1O</smiles>

2
3

Fig.-1: Isolated Compounds from S. tetrasperma Roxb Bark; $\beta$-Sitosterol Glucoside (1), 3,4-Dihydroxybenzoic Acid (2), 2-(Hydroxymethyl) Phenol (3), 3-(Hydroxymethyl) Phenol (5), 4-Methylbenzaldehyde (6), and from the Leaves; 1,2-Dihydroxybenzene (7) and 3',4',5,7-Tetrahydroxyflavone (8).

Furthermore, six methyl protons appeared in the $\mathrm{H}$ NMR spectrum as singlet protons at $\delta_{\mathrm{H}} 0.65(\mathrm{H}-18)$ and $0.83(\mathrm{H}-19)$, doublet protons at $\delta_{\mathrm{H}} 0.80(\mathrm{H}-26), 0.81(\mathrm{H}-27), 0.89(\mathrm{H}-21)$, and $0.95(\mathrm{H}-29)$ respectively. On the other hand, the sugar moiety protons resonated at $\delta_{\mathrm{H}} 3.05-4.90 \mathrm{ppm}$, while the proton at $\delta_{\mathrm{H}} 4.43 \mathrm{ppm}$ indicated an anomeric proton ( $\left.\mathrm{H}^{-1}{ }^{\prime}\right)$. The C NMR spectrum of $\mathbf{1}$ appeared 35 carbon signals including 29 signals of a steroidal compound and 6 signals of glucose moiety in its structure. The signals at $\delta_{\mathrm{C}} 140.44$ and $121.22 \mathrm{ppm}$ showed the occurrence of olefinic carbons at C-5 and C-6, respectively. Meanwhile, the signal at $\delta_{\mathrm{C}} 76.87 \mathrm{ppm}$ indicated oxymethine carbon at C-3. Moreover, six methyl carbon signals appeared at $\delta_{\mathrm{C}} 11.68$ (C-18), 11.79 (C-29), 18.62 (C-21), 18.94 (C-27), 19.11 (C19 ), and 19.72 (C-26). The remaining six signals at $\delta_{\mathrm{C}} 100.77$ (C-1'), 73.47 (C-2'), 76.91 (C-3'), 70.11 (C-4'), 76.75 (C-5') and 61.10 (C-6') were assigned for sugar moiety. Based on H and C NMR spectral data, and compared to related literature, compound 1 was identified as $\beta$-sitosterol glucoside. ${ }^{13-15}$

Compound $\mathbf{2}$ was obtained as a yellow crystal $(8 \mathrm{mg})$. The H NMR spectrum of $\mathbf{2}$ showed three aromatic protons at $\delta_{\mathrm{H}} 7.33(\mathrm{~d}, 1 \mathrm{H}, J=2.1 \mathrm{~Hz}, \mathrm{H}-2), 7.28(\mathrm{dd}, 1 \mathrm{H}, J=8.2 ; 2.1 \mathrm{~Hz}, \mathrm{H}-6)$, and $6.77(\mathrm{~d}, 1 \mathrm{H}, J=8.2$ $\mathrm{Hz}, \mathrm{H}-5)$, while six aromatic signals at $\delta_{\mathrm{c}} 115.81,150.60,145.41,122.73,122.20,117.08 \mathrm{ppm}$, and one carbonyl signal at $\delta_{\mathrm{c}} 168.24 \mathrm{ppm}$ appeared in C NMR spectrum. In ${ }^{1} \mathrm{H}-{ }^{1} \mathrm{H}$ COSY spectrum, the proton at $\delta_{\mathrm{H}} 7.28 \mathrm{ppm}$ exhibited meta-coupling with the proton at $\delta_{\mathrm{H}} 7.33 \mathrm{ppm}(J=2.1 \mathrm{~Hz})$ and it also had orthocoupling with the proton at $\delta_{\mathrm{H}} 6.77 \mathrm{ppm}(J=8.2 \mathrm{~Hz})$, that assigned trisubstitution at 1,3 and 4 positions in the aromatic ring. A broad singlet signal in the most downfield region $\left(\delta_{\mathrm{H}} 12.28 \mathrm{ppm}\right)$ assigned the occurrence of carboxylic acid bound to the aromatic ring of 2 . By $\mathrm{H}$ and $\mathrm{C}$ NMR analyses and comparison with the previously reported data, the chemical structure of 2 was determined as 3,4dihydroxybenzoic acid or protocatechuic acid. ${ }^{16-18}$

Compound 3 was isolated as an orange crystal $(6 \mathrm{mg})$. The H NMR of 3 displayed four aromatic protons and an oxidized methylene proton $\left(\delta_{\mathrm{H}} 4.71 \mathrm{ppm}\right)$. The most downfield proton at $\delta_{\mathrm{H}} 7.21 \mathrm{ppm}$ revealed ortho-coupling with the proton at $\delta_{\mathrm{H}} 6.78 \mathrm{ppm}(J=7.32 \mathrm{~Hz})$, while the proton at $\delta_{\mathrm{H}} 7.07 \mathrm{ppm}$ as a triplet 
RASĀYAN J. Chem.

Vol. 13 | No. 2 |796 - 802| April - June | 2020

also showed ortho-coupling with the protons at $\delta_{\mathrm{H}} 6.78$ and $6.77 \mathrm{ppm}(J=8.24 \mathrm{~Hz})$. The C NMR indicated seven carbon signals including six aromatic carbons at $\delta_{\mathrm{C}} 155.36(\mathrm{C}-1), 127.99(\mathrm{C}-3), 127.53$ $(\mathrm{C}-5), 127.45$ (C-2), $119.32(\mathrm{C}-4), 115.17 \mathrm{ppm}(\mathrm{C}-6)$ and one oxidized methylene carbon $\left(\delta_{\mathrm{C}} 61.02 \mathrm{ppm}\right)$ bound to aromatic carbon, respectively. Based on the comparison of $\mathrm{H}$ and $\mathrm{C}$ NMR data with the literature, the structure of compound $\mathbf{3}$ was assigned as 2-(hydroxymethyl)phenol or salicyl alcohol. ${ }^{19}$

Compound 4 was acquired as a white pale crystal $(4 \mathrm{mg})$. The H NMR spectrum showed three aromatic protons. While, four signal aromatic carbons $\left(\delta_{\mathrm{C}} 135.9,130.45,119\right.$, and $\left.117 \mathrm{ppm}\right)$ appeared in the $\mathrm{C}$ NMR spectrum. The proton at $\delta_{\mathrm{H}} 7.51 \mathrm{ppm}(\mathrm{td}, 1 \mathrm{H})$ had ortho-coupled with two protons at $\delta_{\mathrm{H}} 6.91 \mathrm{ppm}$ (dd, $J=8 \mathrm{~Hz}$ ) and also had para-coupling with a proton at $\delta_{\mathrm{H}} 7.87 \mathrm{ppm}(\mathrm{dd}, J=1.84 \mathrm{~Hz}$ ). It is predicted that the aromatic ring had two hydroxyl groups at 1,3-position. Based on the comparing spectral data of 4 with literature, it was identified as 1, 3-dihydroxyphenol or resorcinol. ${ }^{20}$

Compound 5 was obtained as an orange crystal $(10 \mathrm{mg})$. The H NMR signal of $\mathbf{5}$ showed the presence of four aromatic protons at $\delta_{\mathrm{H}} 7.21 \mathrm{ppm}(\mathrm{td}, 1 \mathrm{H}, J=8 ; 0.92 \mathrm{~Hz}, \mathrm{H}-5), 7.03 \mathrm{ppm}(\mathrm{dd}, 1 \mathrm{H}, J=8 ; 1.36 \mathrm{~Hz}, \mathrm{H}-$ 6), $6.87 \mathrm{ppm}(\mathrm{dd}, 1 \mathrm{H}, J=1.36 ; 0.92 \mathrm{~Hz}, \mathrm{H}-4)$, and $6.84 \mathrm{ppm}(\mathrm{dd}, 1 \mathrm{H}, J=8 ; 1.36 \mathrm{~Hz}, \mathrm{H}-2)$, respectively and one oxidized methylene proton at $\delta_{\mathrm{H}} 4.71 \mathrm{ppm}(\mathrm{s}, 2 \mathrm{H}, \mathrm{H}-7)$. This compound assigned two substituents bound to the aromatic ring. It was suggested that the hydroxyl and hydroxymethyl groups were separately attached to carbon at $\delta_{\mathrm{C}} 156.14(\mathrm{C}-1)$ and $\delta_{\mathrm{C}} 129.61(\mathrm{C}-3)$. Compared to the spectral data of $\mathbf{5}$ with the literature, the chemical structure of $\mathbf{5}$ was determined as 3-(hydroxymethyl) phenol. ${ }^{20-21}$

Compound 6 was isolated as a brownish crystal $(3 \mathrm{mg})$. Its $\mathrm{H}$ NMR showed two set double-doublet protons at $\delta_{\mathrm{H}} 7.87 \mathrm{ppm}(\mathrm{dd}, 2 \mathrm{H}, J=8 ; 4 \mathrm{~Hz}, \mathrm{H}-2$ and $\mathrm{H}-6)$ and $\delta_{\mathrm{H}} 6.90 \mathrm{ppm}(\mathrm{dd}, 2 \mathrm{H}, J=8 ; 4 \mathrm{~Hz}, \mathrm{H}-3$ and $\mathrm{H}-5$ ) assigned symmetric pattern of the aromatic ring with substitution at 1 and 4 positions. A broad singlet signal at $\delta_{\mathrm{H}} 9.13 \mathrm{ppm}$ indicated the presence of carbonyl group, while the remaining of three protons at $\delta_{\mathrm{H}} 2.46 \mathrm{ppm}(\mathrm{s}, 3 \mathrm{H})$ assigned the presence of methyl group bound to the aromatic ring. The $\mathrm{C}$ NMR spectrum displayed six-carbon signals, consist of four aromatic carbons at $\delta_{\mathrm{C}} 161.86,130.78$, 129.66 , and $115.18 \mathrm{ppm}$, one carbonyl carbon at $\delta_{\mathrm{C}} 195.72 \mathrm{ppm}$, and one methyl carbon at $\delta_{\mathrm{C}} 28.90 \mathrm{ppm}$, respectively. After comparing the spectral data of $\mathbf{6}$ with literature, it was assigned as 4methylbenzaldehyde. ${ }^{22-23}$

Compound 7 was obtained as a colorless crystal $(70 \mathrm{mg})$. $\mathrm{H}$ and C NMR spectrum displayed only two aromatic proton signals as multiplet separately at $\delta_{\mathrm{H}} 6.67 \mathrm{ppm}\left(\mathrm{H}-3\right.$ and H-6) and $\delta_{\mathrm{H}} 6.82 \mathrm{ppm}(\mathrm{H}-4$ and $\mathrm{H}-5)$, and three aromatic carbon signals $\left(\delta_{\mathrm{C}} 115.38,119.97,145.14 \mathrm{ppm}\right)$. Compared to the spectral data of 7 with literature, it was identified as 1, 2-dihydroxyphenol or catechol. ${ }^{4}$

Compound $\mathbf{8}$ was acquired as a yellow amorphous powder $(40 \mathrm{mg})$. The H NMR spectrum of $\mathbf{8}$ contained six aromatic proton signals. Two aromatic protons signal at $\delta_{\mathrm{H}} 6.43 \mathrm{ppm}(1 \mathrm{H}, \mathrm{d}, J=2.04 \mathrm{~Hz})$ and $\delta_{\mathrm{H}} 6.20$ $\operatorname{ppm}(1 \mathrm{H}, \mathrm{d}, J=2.04 \mathrm{~Hz})$ showed meta-coupling proton and suggested that two protons are attached at C8 and C-6 of the A ring of the flavone skeleton. Furthermore, the presence of aromatic proton signals at $\delta_{\mathrm{H}} 7.38 \mathrm{ppm}(1 \mathrm{H}, \mathrm{d})$ and $\delta_{\mathrm{H}} 6.90 \mathrm{ppm}(1 \mathrm{H}, \mathrm{d})$ indicated an ortho-coupling proton of B ring $(J=8.94 \mathrm{~Hz})$. The addition of aromatic proton at $\delta_{\mathrm{H}} 7.37 \mathrm{ppm}$ resonated meta-coupled with the proton at $\delta_{\mathrm{H}} 7.38 \mathrm{ppm}(J$ $=2.74 \mathrm{~Hz}$ ). The C NMR and DEPT 135 spectra comparison showed 8 contained six methines and nine quaternary carbons. In HMBC spectrum, two ortho-coupling protons of B ring $\left(\delta_{\mathrm{H}} 7.38\right.$ and $\left.6.90 \mathrm{ppm}\right)$ showed long-range correlations to C-2 $\left(\delta_{\mathrm{C}} 164.65 \mathrm{ppm}\right), \mathrm{C}-4$ ' ( $\left.\delta_{\mathrm{C}} 149.64 \mathrm{ppm}\right), \mathrm{C}-3^{\prime}$ ( $\left.\delta_{\mathrm{C}} 145.70 \mathrm{ppm}\right)$, and $\mathrm{C}-1^{\prime}\left(\delta_{\mathrm{C}} 122.33 \mathrm{ppm}\right)$ suggested that two hydroxyl groups are attached at C-3' and C-4'. A remaining proton as a singlet at $\delta_{\mathrm{H}} 6.53 \mathrm{ppm}$ exhibited long-range correlations to $\mathrm{C}-10\left(\delta_{\mathrm{C}} 103.96 \mathrm{ppm}\right)$, and $\mathrm{C}-1$ ' $\left(\delta_{\mathrm{C}} 122.33 \mathrm{ppm}\right)$, indicated that proton is attached to the $\mathrm{C}-3$ position of $\mathrm{C}$ ring. According to the HMBC spectrum, a hydroxyl group was suggested bound at C-5, C-7, C-3', and C-4' positions of 8. In comparison, the NMR data of $\mathbf{8}$ with the related literature data, ${ }^{24-25}$ compound $\mathbf{8}$ was confirmed as 3',4',5,7-tetrahydroxyflavone or luteolin.

\section{Antioxidant Activity}

The DPPH radical scavenging results of $S$. tetrasperma Roxb barks, root, and leaves extracts were assayed as described in Materials and Methods. The highest antioxidant scavenging among the nine different extracts was in the $\mathrm{MeOH}$ extract of the bark, while the minimum was found in the $n$-hexane extract of the root (Table-1). All MeOH extracts possessed strong antioxidant activity with $\mathrm{IC}_{50}$ value of bark, root, and leaves as $6.85 \pm 0.05 ; 16.93 \pm 0.12$; and $27.43 \pm 0.44 \mu \mathrm{g} / \mathrm{mL}$, respectively. The activity of 
RASĀYAN J. Chem.

Vol. 13 | No. 2 |796 - 802 | April - June | 2020

EtOAc extract of the root $\left(\mathrm{IC}_{50} 19.53 \pm 0.22 \mu \mathrm{g} / \mathrm{mL}\right)$ was stronger than that of the bark $\left(\mathrm{IC}_{50} 22.69 \pm 0.29\right.$ $\mu \mathrm{g} / \mathrm{mL}$ ), whereas the EtOAc extract of the leaves was not active $\left(\mathrm{IC}_{50} 142.18 \pm 1.29 \mu \mathrm{g} / \mathrm{mL}\right)$ and also all parts of $n$-hexane extracts. Compared to the positive control, all tested samples showed lower scavenging activity than ascorbic acid $\left(\mathrm{IC}_{50} 2.19 \pm 0.04 \mu \mathrm{g} / \mathrm{mL}\right)$.

Table-1: Antioxidant Activity of S. tetrasperma Roxb Extracts (mean $\pm \mathrm{SD}$ ), $n=3$

\begin{tabular}{l|c|c}
\hline Extract & Part & $\mathrm{IC}_{50}(\mu \mathrm{g} / \mathrm{mL}) \pm \mathrm{SD}$ \\
\hline \multirow{2}{*}{-Hexane } & Root & $916.35 \pm 13.15$ \\
\cline { 2 - 3 } & Bark & $487.36 \pm 2.78$ \\
\hline \multirow{2}{*}{ Ethyl acetate } & Root & $19.53 \pm 0.22$ \\
\cline { 2 - 3 } & Bark & $22.69 \pm 0.29$ \\
\cline { 2 - 3 } & Leaves & $142.18 \pm 1.29$ \\
\hline \multirow{2}{*}{ Methanol } & Root & $16.93 \pm 0.12$ \\
\cline { 2 - 3 } & Bark & $6.85 \pm 0.05$ \\
\cline { 2 - 3 } & Leaves & $27.43 \pm 0.44$ \\
\hline Ascorbic acid & - & $2.19 \pm 0.04$
\end{tabular}

The number of electrons taken up is very important for antioxidant scavenging activity. This is due to the ability of hydrogen donors from polyphenol compounds and also the correlation with the total flavonoid content contained in the extract. ${ }^{26-27}$ Our phytochemical investigation showed that the presence of phenolic and flavonoid in $\mathrm{MeOH}$ and EtOAc extract of the bark and leaves of $S$. tetrasperma Roxb might contribute to the high antioxidant activity. Thus, this plant can be considered as a good natural antioxidant source.

\section{CONCLUSION}

The chemical constituents of $S$. tetrasperma Roxb were evaluated by isolating six compounds from EtOAc extract the bark such as $\beta$-sitosterol glucoside (1), 3,4-dihydroxybenzoic acid (2), 2(hydroxymethyl)phenol (3), 1,3-dihydroxyphenol (4), 3-(hydroxymethyl)phenol (5), 4methylbenzaldehyde (6) and two compounds from EtOAc extract of $S$. tetrasperma Roxb leaves as 1,2dihydroxybenzene (7) and 3',4',5,7-tetrahydroxyflavone (8). MeOH extract from the bark, root, and leaves of $S$. tetrasperma Roxb had a strong antioxidant activity with $\mathrm{IC}_{50}$ value of $6.85 \pm 0.05 ; 16.93 \pm 0.12$; and $27.43 \pm 0.44 \mu \mathrm{g} / \mathrm{mL}$, respectively.

\section{ACKNOWLEDGEMENT}

This study was financially funded by The Ministry of Research Technology of the Republic of Indonesia through the PMDSU scholarship with the grant number: 16/H.16/PMDSU/LPPM/2016. The authors would also like to thank Prof. Mamoru Koketsu, Ph.D. and Mr. Antoni Pardede, Ph.D., for their aid in supporting NMR measurement and lab assistant at the Department of Chemistry and Biomolecular Science, Faculty of Engineering, Gifu University, Japan.

\section{REFERENCES}

1. R. R. Chhetree, G. K. Dash, S. Mondal and R. Parhi, International Journal of Drug Development \& Research, 2(4), 799(2010)

2. K. T. R. Prashith, K. S. Vinayaka and K. S. K. Praveen, International Journal of Herbal Medicine, 5(5), 192(2017)

3. J. H. Virupaksha, R. R. Nadendla and M. Satishkumar, International Journal of Pharma and Bio Sciences, 7(3), 89(2016)

4. A. El-Shazly, A. El-Sayed and E. Fikrey, Zeitschrift Fur Naturforschung Section C-A Journal of Biosciences Verlag Z Naturforsc, 67, 353(2012), DOI:10.1515/znc-2012-7-801

5. F. Utari, A. Itam, S. Syafrizayanti, W. H. Putri, M. Ninomiya, M. Koketsu, K. Tanaka and M. Efdi, Journal of Applied Pharmaceutical Science, 9(8), 53(2019), DOI:10.7324/JAPS.2019.90808

6. A. Kakumu, M. Ninomiya, M. Efdi, M. Adfa, M. Hayashi, K. Tanaka and M. Koketsu, Bioorganic \& Medicinal Chemistry Letters, 24(17), 4286(2014), DOI:10.1016/j.bmcl.2014.07.022 
RASĀYAN J. Chem.

Vol. 13 | No. 2 |796 - 802| April - June | 2020

7. C. S. Kim, L. Subedi, K. J. Park, S. Y. Kim, S. U. Choi, K. H. Kim and K. R. Lee, Fitoterapia, 106, 147 (2015), DOI:10.1016/j.fitote.2015.08.013

8. Z. A. Shah, A. Hameed, A. Ahmed, S. U. Simjee, A. Jabeen, A. Ullah and F. Shaheen, Phytochemistry Letters, 17, 107(2016), DOI:10.1016/j.phytol.2016.07.013

9. P. J. Masika, N. Sultana, A. J. Afolayan and P. J. Houghton, South African Journal of Botany, 71(3\&4), 441(2005), DOI:10.1016/S0254-6299(15)30117-4

10. R. Januarti, A. Santoni and M. Efdi, Indonesian Journal of Fundamental and Applied Chemistry, 4(2), 42(2019), DOI:10.24845/ijfac.v4.i2.42

11. S. Ramadhani, A. Santoni and M. Efdi, Indonesian Journal of Fundamental and Applied Chemistry, 4(2), 47(2019), DOI:10.24845/ijfac.v4.i2.47

12. S. Sen, B. De, N. Devanna and R. Chakraborty, Chinese Journal of Natural Medicines, 11(2), 149 (2013), DOI:10.1016/S1875-5364(13)60042-4

13. M. Arora and A. N. Kalia, International Journal of Pharmacy and Pharmaceutical Science, 5(1), 245(2013)

14. N. M. M. U. Khan and M. S. Hossain, Journal of Pharmacognosy and Phytochemistry, 4(2), 05 (2015)

15. T. Peshin and H. Kar, British Journal of Pharmaceutical Research, 16(4), 1(2017)

16. X. H. Nguyen, K. W. Naing, Y. S. Lee, J. H. Moon, J. H. Lee and K. Y. Kim, Journal of Basic Microbiology, 54, 625(2015)

17. B. A. Ayinde, D. N. Onwukaeme and E. K. Omogbai, Acta Poloniae Pharmaceutica N Drug Research, 64(2), 183(2007)

18. T. Rho and K. D. Yoon, Natural Product Sciences, 23(4), 253(2017)

19. H. Cong, T. Yamato and Z. Tao, New Journal of Chemistry, 37, 3778(2013), DOI: $10.1039 / \mathrm{c} 3 \mathrm{nj} 00660 \mathrm{c}$

20. P. Reveglia, S. Savocchia, R. B. Baaijens, A. Cimmino and A. Evidente, Journal of Agricultural and Food Chemistry, 66(8), 1760(2018), DOI:10.1021/acs.jafc.7b05248

21. C. G. Kumar, P. Mongolla, S. Pombala, S. Bandi, K. S. Babu and K. V. S. Ramakrishna, Journal of Applied Microbiology, 122, 1518(2017), DOI:10.1111/jam.13450

22. B. Zhao, R. Shang, W. M. Cheng and Y. Fu, Organic Chemistry Frontiers, 5(11), 1782(2018), DOI: $10.1039 / \mathrm{C} 8 \mathrm{QO} 00253 \mathrm{C}$

23. Y. Zhang, X. Jiang, J. M. Wang, J. L. Chen and Y. M. Zhu, RSC Advances, 5(22), 17060(2015), DOI: $10.1039 / \mathrm{C} 4 \mathrm{RA} 16388 \mathrm{E}$

24. A. Wahab, Tahira, S. Begum, A. Ayub, I. Mahmood, T. Mahmood, A. Ahmad and N. Fayyaz, FUUAST Journal of Biology, 4(1), 1(2014)

25. O. J. Ode and I. U. Asuzu, IOSR Journal of Pharmacy, 4(10), 17(2014).

26. S. Enayat and S. Banerjee, Food Chemistry, 116, 23(2009), DOI:10.1016/j.foodchem.2009.01.092

27. M. K. N. Al-Ghudani and M. A. Hossain, Asian Pacific Journal of Tropical Disease, 5(1), S155(2015), DOI:10.1016/S2222-1808(15)60879-9

[RJC-5547/2019] 